\title{
THE INFLUENCE OF THE TIME OF ANTIDOTAL TREATMENT ADMINISTRATION ON ITS EFFECTIVENESS AGAINST TABUN-INDUCED POISONING IN MICE
}

\author{
Jiři Kassa \\ Purkyně Military Medical Academy, Hradec Králové, Czech Republic: Department of Toxicology
}

\begin{abstract}
Summary: 1. The influence of the time of administration of antidotal treatment consisting of anticholinergic drug (atropine) and oxime (pralidoxime, obidoxime, HI-6 or trimedoxime) on its effectiveness to eliminate tabun-induced lethal effects was studied in mice. 2. The therapeutic efficacy of antidotal treatment of tabun-induced acute poisoning depends on the time of its administration when obidoxime or the oxime HI-6 was used as an acetylcholinesterase reactivator. 3. Pralidoxime is practically ineffective to eliminate acute toxic effects of tabun regardless of the time of its administration. 4. Our results show that trimedoxime seems to be the most effective to eliminate lethal effects of tabun. In addition, its efficacy does not decrease when it is administered $5 \mathrm{~min}$ after tabun poisoning. 5 . The findings support the hypothesis that trimedoxime appears to be the most suitable oxime to counteract acute toxicity of tabun because of its ability to eliminate lethal effects of tabun when it is injected 5 min after tabun challenge on the contrary to other oximes tested.
\end{abstract}

Key words: Tabun; Pralidoxime; Obidoxime; HI-6; Trimedoxime; Acute toxicity; Mice

\section{Introduction}

Despite the entry into force in April 1997 of the Chemical Weapons Convention forbidding the development, production, stockpiling and use of chemical warfare agents, the world has seen a rapid proliferation of such agents (19). The chemical warfare agents include nerve agents, highly toxic organophosphorus compounds (OPs) that exert their toxic effects by phosphonylation and subsequent inactivation of acetylcholinesterase (AChE, EC 3.1.1.7). The inactivation of this enzyme allows the accumulation of acetylcholine $(\mathrm{ACh})$ in the synaptic terminals of the central and peripheral nervous systems with subsequent widespread overstimulation of cholinergic receptors $(17,22)$. Despite the long-term knowledgement of the basic mechanism of their acute toxicity, some highly toxic OPs were found to be resistant to the standard antidotal treatment which consists of anticholinergic drugs to counteract the accumulation of $\mathrm{ACh}$ and oximes to reactivate nerve agentinhibited AChE $(1,8)$.

Tabun (O-ethyl-N,N-dimethyl phosphoramidocyanidate) is probably one of the most dangerous compounds among nerve agents, since its deleterious effects are extraordinarily difficult to counteract because of the existence of a lone electron pair located on an amidic group that makes the nucleophilic attack of oximes almost impossible $(2,4$, $5,7,14)$.
The ability of currently used monopyridinium (e.g. pralidoxime) and bispyridinium oximes (e.g. pralidoxime, obidoxime, HI-6) in combination with atropine to eliminate acute toxic effects of nerve agents is rather low regardless of the choice of oxime $(7,13,14)$. It is known that the efficacy of antidotes depends on their therapeutic dose that it is limited by their toxicity. Based on our experimental results, the reactivating efficacy of the oxime HI-6 to reactivate tabun-inhibited $\mathrm{AChE}$ is lower compared to obidoxime (16) but it can be administered in higher dose than obidoxime due to its lower toxicity and, therefore, its efficacy to eliminate acute lethal effects of tabun is comparable with the effectiveness of obidoxime when they are administered at equieffective, human relevant doses $(2 \%$ $\mathrm{LD}_{50)}$ (11).

Another fact influencing the efficacy of antidotal treatment of poisonings with nerve agents is the time interval between nerve agent exposure and the administration of antidotes. It is expected that the shortening of the time between nerve agent poisoning and the administration of antidotes should bring higher potency of antidotes to eliminate acute lethal effects of tabun (9). The present study investigates the influence of the time of antidotal mixture administration on the efficacy of currently used oximes (pralidoxime, obidoxime, trimedoxime, HI-6) in combination with atropine against tabun-induced acute poisoning in mice. 


\section{Methods}

Male mice weighing between 20 and $25 \mathrm{~g}$ were obtained from Konárovice. The animals were maintained in an air-conditioned room with light from 07.00 to $19.00 \mathrm{~h}$ and were allowed free access to standard food and tap water. The principles of laboratory animal care were followed and the handling of animals was made under the supervision of the Ethics Committee of Medical Faculty of Charles University and Purkyně Military Medical Academy in Hradec Králové.

Tabun of $95 \%$ purity was purchased from Military Technical Institute Brno. Its purity was assayed by acidimetric titration. The oxime HI- 6 of $98.5 \%$ purity was synthesized at the Department of Toxicology of Purkyně Military Medical Academy in Hradec Králové. Its purity was analyzed using HPLC. All other chemicals and drugs of analytical grade were obtained commercially and used without further purification.
In our experiments, tabun-poisoned mice were treated intramuscularly (i.m.) with one of tested oximes (pralidoxime, obidoxime, trimedoxime and the oxime HI-6) at equieffective doses $\left(2 \% \mathrm{LD}_{50}\right)$ in combination with atropine $(21 \mathrm{mg} / \mathrm{kg}$ ) one, three or five min after i. m. challenge of tabun.

The effectiveness of tested antidotal mixtures was evaluated by the assessment of the $\mathrm{LD}_{50}$ values and their $95 \%$ confidence limits using probit-logarithmical analysis of death occuring within $24 \mathrm{~h}$ after i.m. administration of tabun at five different doses with six mice per dose (21). The efficacy of tested antidotal mixtures was expressed as protective ratio $\mathrm{A}\left(\mathrm{LD}_{50}\right.$ value of tabun in protected mice/ $\mathrm{LD}_{50}$ value of tabun in unprotected mice). The influence of the time of antidotal mixture administration was expressed as protective ratio $B\left(\mathrm{LD}_{50}\right.$ value of tabun in mice protected at 3 or 5 min following tabun poisoning/ $\mathrm{LD}_{50}$ value of tabun in mice protected at $1 \mathrm{~min}$ following tabun poisoning).

Tab. 1: The influence of the time of administration of pralidoxime in combination with atropine on its potency to eliminate acute lethal effects of tabun. "significantly different from the untreated group at the level of $p<0.05$, ${ }^{\mathrm{x}}$ significantly different from the group treated at 1 min following tabun poisoning at the level of $p<0.05$.

\begin{tabular}{|c|c|c|c|c|}
\hline Treatment & Time of treatment & $\mathbf{L D}_{\mathbf{5 0}}(\boldsymbol{\mu} \mathbf{g} / \mathbf{k g}) \mathbf{\pm} \mathbf{9 5} \% \mathbf{I S}$ & Protective ratio A & Protective ratio B \\
\hline- & - & $295.9(275.5-317.9)$ & - & - \\
\hline \multirow{2}{*}{$\begin{array}{c}\text { Pralidoxime } \\
+ \\
\text { atropine }\end{array}$} & $1 \mathrm{~min}$ & $329.3(313.3-346.2)$ & 1.11 & - \\
\cline { 2 - 5 } & $3 \mathrm{~min}$ & $328.3(314.0-343.3)$ & 1.11 & 1.00 \\
\cline { 2 - 5 } & $5 \mathrm{~min}$ & $303.9(290.3-318.2)$ & 1.03 & 0.92 \\
\hline
\end{tabular}

Tab. 2: The influence of the time of administration of obidoxime in combination with atropine on its potency to eliminate acute lethal effects of tabun. Statistical significance - see Table 1.

\begin{tabular}{|c|c|c|c|c|}
\hline Treatment & Time of treatment & $\mathbf{L D}_{\mathbf{5 0}}(\boldsymbol{\mu g} \mathbf{/ k g}) \mathbf{\pm 9 5 \%} \mathbf{~ I S}$ & Protective ratio A & Protective ratio B \\
\hline- & - & $295.9(275.5-317.9)$ & - & - \\
\hline \multirow{2}{*}{$\begin{array}{c}\text { Obidoxime } \\
+\end{array}$} & $1 \mathrm{~min}$ & $435.7(410.9-461.9)^{*}$ & 1.47 & - \\
\cline { 2 - 5 } atropine & $3 \mathrm{~min}$ & $384.1(351.2-420.1)^{*}$ & 1.30 & 0.88 \\
\cline { 2 - 5 } & $5 \mathrm{~min}$ & $347.4(333.6-361.9)^{* \mathrm{X}}$ & 1.17 & 0.80 \\
\hline
\end{tabular}

Tab. 3: The influence of the time of administration of the oxime HI-6 in combination with atropine on its potency to eliminate acute lethal effects of tabun. Statistical significance - see Table 1.

\begin{tabular}{|c|c|c|c|c|}
\hline Treatment & Time of treatment & $\mathbf{L D}_{\mathbf{5 0}}(\boldsymbol{\mu g} / \mathbf{k g}) \mathbf{\pm 9 5} \% \mathbf{I S}$ & Protective ratio A & Protective ratio B \\
\hline- & - & $265.9(249.1-283.9)$ & - & - \\
\hline \multirow{2}{*}{$\begin{array}{c}\text { HI-6 } \\
+\end{array}$} & $1 \mathrm{~min}$ & $435.2(410.4-461.4)^{*}$ & 1.64 & - \\
\cline { 2 - 5 } atropine & $3 \mathrm{~min}$ & $414.0(386.6-443.3)^{*}$ & 1.55 & 0.95 \\
\cline { 2 - 5 } & $5 \mathrm{~min}$ & $322.8(288.6-361.0)^{* \mathrm{X}}$ & 1.21 & 0.74 \\
\hline
\end{tabular}

Tab. 4: The influence of the time of administration of trimedoxime in combination with atropine on its potency to eliminate acute lethal effects of tabun. Statistical significance - see Table 1.

\begin{tabular}{|c|c|c|c|c|}
\hline Treatment & Time of treatment & $\mathbf{L D}_{\mathbf{5 0}}(\boldsymbol{\mu g} / \mathbf{k g}) \pm \mathbf{9 5} \% \mathbf{I S}$ & Protective ratio A & Protective ratio B \\
\hline- & - & $320.4(310.6-330.6)$ & - & - \\
\hline \multirow{2}{*}{$\begin{array}{c}\text { Trimedoxime } \\
+ \\
\text { atropine }\end{array}$} & $1 \mathrm{~min}$ & $549.3(513.6-587.4)^{*}$ & 1.71 & - \\
\cline { 2 - 5 } & $3 \mathrm{~min}$ & $545.0(488.4-608.1)^{*}$ & 1.70 & 0.99 \\
& $5 \mathrm{~min}$ & $510.2(477.4-545.3)^{*}$ & 1.59 & 0.93 \\
\hline
\end{tabular}


Statistical significance was determined by the use of Student's t-test and differences were considered significant when $\mathrm{p}<0.05$.

\section{Results}

The evaluation of therapeutic efficacy of antidotal mixtures consisting of various oximes in combination with atropine administered at various time intervals following tabun challenge is summarized in Tables 1-4. These results show that the efficacy of tested antidotal mixtures is decreasing when the time interval between tabun poisoning and antidotal treatment is prolonged regardless of the choice of the oxime. Nevertheless, the difference of the therapeutical efficacy of tested antidotal mixtures administered at various time intervals following tabun poisoning is significant in the case of usage of obidoxime or the oxime HI-6 only $(p<0.05)$ (Table 2,3). The decrease in the potency of pralidoxime and trimedoxime to eliminate tabun-induced acute toxicity with the prolonged time interval between tabun poisoning and antidotal treatment is negligible (Table 1,4).

To compare the potency of oximes, administered at the same time after tabun poisoning, to eliminate lethal effects of tabun, trimedoxime seems to be the most efficacious reactivator of tabun-inhibited $\mathrm{AChE}$ in the elimination of tabun-induced acute toxic effects in mice, when the antidotal treatment is administered at 5 min following tabun poisoning $(\mathrm{p}<0.05)$. On the other hand, pralidoxime seems to be the weakest reactivator of tabun-inhibited AChE in the elimination of tabun-induced acute toxicity regardless of the time interval between tabun challenge and antidotal treatment (Tables 1-4).

\section{Discussion}

Nerve agents are still considered to be the most important chemical warfare agents. With the existing threat of the use of chemical weapons not only in military conflicts but also in terroristic attacks, the search for effective protection is the central concern of different laboratories both civilian and military $(4,18)$.

The effectiveness of antidotal treatment of acute poisoning with tabun is not sufficient regardless of the choice of the oxime because tabun-inhibited AChE is very difficult to reactivate $(3,7,20,23)$. The reason for the weak reactivation potency of the oximes is not the rate of aging of phosphonylated AChE that is relatively low (6) but the presence of a lone electron pair located on an amidic nitrogen. This lone electron pair makes the nucleophilic attack very difficult (5). Due to the relatively low efficacy of antidotal treatment against tabun, it is necessary to optimize the dose of antidotes and the time of antidotal administration. The previous results confirm the importance of the dose of oximes to counteract lethal effects of tabun (11). Generally, low toxicity of oximes makes possible to use them at higher therapeutical doses. The oxime HI-6 is as efficacious as obidoxime at equieffective doses to eliminate lethal effects of tabun due to its low toxicity (11) although it is weaker reactivator of tabun-inhibited AChE compared to obidoxime $(3,7,20,23)$.

Our resultts confirm that the time af administration of antidotes following tabun poisoning is also very important. Commonly, the efficacy of antidotal treatment rapidly decreases when the time of its administration following tabun poisoning is prolonged. Nevertheless, the dependence of the efficacy of antidotes on the time of their administration is different for each oxime. While the therapeutic efficacy of mostly used oximes (obidoxime and the oxime HI-6) significantly depends on the time of their administration after tabun challenge, this dependence is not so strong in the case of usage of pralidoxime or trimedoxime but for different reasons. Pralidoxime is practically ineffective to eliminate lethal effects of tabun $(10,12,15)$ and, therefore, the time of its administration can not influence its efficacy. On the other hand, trimedoxime is considered to be the most efficacious oxime to counteract lethal effects of tabun (11) and, therefore, its dependence on the time of administration is not so strong compared to obidoxime and the oxime HI-6. The efficacy of trimedoxime to eliminate tabun-induced lethal effects seems to be relatively sufficient on the contrary of other tested oximes when it is administered in combination with atropine till 5 min following tabun poisoning.

In conclusion, our data indicate the necessity to administer the first dose of antidotes as soon as possible following exposure to tabun because the factor of the time seems to be very important for the efficacy of antidotal treatment to counteract the acute lethal effects of tabun. In addition, the correct choice of $\mathrm{AChE}$ reactivator is also very important for the survival of tabun-poisoned experimental animals because there is a significant difference in the efficacy of currently used oximes to eliminate tabun-induced acute toxic effects in tabun-poisoned mice.

\section{Acknowledgement}

The author thanks to Mrs J. Uhlírová for her technical assistance and help with statistical evaluation. The study was supported by the Grant of Ministry of Defence, OBVLAJEP20032.

\section{References}

1. Bajgar J, Fusek J, Vachek J. Treatment and prophylaxis against nerve agent poisoning. ASA Newslett 1994;94(4):10-1.

2. Cabal J, Bajgar J. Tabun - návrat po padesáti letech. Chem Listy 1999;93:27-31

3. Clement JG, Shiloff JD, Gennings C. Efficacy of a combination of acetylcholinesterase reactivators, HI-6 and obidoxime, against tabun and soman poisoning in mice. Arch Toxicol 1987;61:70-5.

4. Dawson RM. Review of oximes available for the treatment of nerve agent poisoning. J Appl Toxicol 1994;14:317-31.

5. Eto M. Organophosphorus pesticides: Organic and biological chemistry. Cleveland: CRC Press Inc, 1976:p 142.

6. Jokanovic M. Anticholinesterase activity and delayed neurotoxic effects of tabun in hens. Vojvosanit Pregl 1993;50:451-6. 
7. Jokanovic M, Maksimovic M, Kilibarda V, Jovanovic D, Savic D. Oxime-induced reactivation of acetylcholinesterase inhibited by phosphoramidates. Toxicol Lett 1996;85:35-9.

8. Kassa J. A comparison of the therapeutic efficacy of conventional and modern oximes against supralethal doses of highly toxic organophosphates in mice. Acta Med (Hradec Králové) 1998;41(1):19-21.

9. Kassa J. Vliv doby podání antidotní terapie na její účinnost vůči toxicitě somanu u myší. Voj zdrav Listy 1999;68(4):93-5.

10. Kassa J. Review of oximes in the antidotal treatment of poisoning by organophosphorus nerve agents. J Toxicol-Clin Toxicol 2002;40(6):803-16.

11. Kassa J. Vliv dávky reaktivátorů acetylcholinesterázy na jejich účinnost při terapii otravy myši tabunem. Čes Slov Farm 2004;53(1):31-4.

12. Kassa J, Cabal J, Bajgar J, Szinicz L. The choice: HI-6, pralidoxime or obidoxime against nerve agents? ASA Newslett 1997;97(4):16-8.

13. Kassa J., Vachek J. A comparison of the efficacy of pyridostigmine alone and the combination of pyridostigmine with anticholinergic drugs as pharmacological pretreatment of tabun-poisoned rats and mice. Toxicology 2002;177:179-85.

14. Koplovitz I, Menton R, Matthews C, Shutz M, Nalls C, Kelly S. Dose-response effects of atropine and HI-6 treatment of organophosphorus poisoning in guinea pigs. Drug Chem Toxicol 1995;18:119-36.

15. Koplovitz I, Stewart JR. A comparison of the efficacy of HI-6 and 2-PAM against soman, tabun, sarin and VX in the rabbit. Toxicol Lett 1994;70:169-79.

16. Kuča K, Kassa J. A comparison of the ability of a new bispyridinium oxime 1-(4-hydroxyiminomethylpyridinium)-4-(4carbamoylpyridinium) butane dibromide and currently used oximes to reactivate nerve agent-inhibited rat brain acetylcholinesterase by in vitro methods. J Enzyme Inhib Med Chem 2003; 18(6): 529-35.

17. Marrs TC. Organophosphate poisoning. Pharmacol Ther 1993;58:51-66
18. Ohtomi S, Takase M, Kumagai F. Sarin poisoning in Japan. A clinical experience in Japan Self Defense Force (JSDF) Central Hospital. Int Rev Arm Se 1996:69:97-102.

19. Polhuijs M, Langenberg JP, Benschop H. New method for retrospective detection of exposure to organophosphorus anticholinesterases: application to alleged sarin victims of Japanese terrorists. Toxicol Appl Pharmacol 1997; 146:156-61.

20. Puu G, Artursson E, Bucht G. Reactivation of nerve agent inhibited acetylcholinesterases by HI-6 and obidoxime. Biochem Pharmacol 1986;35:1505-10.

21. Tallarida R, Murray R. Manual of pharmacological calculation with computer programs. New York, Springer-Verlag:1987:p.145.

22. Taylor P. Anticholinesterase agents. In: The pharmacological basis of therapeutics (Hardman JG, Lombird LE eds.). New York, McGraw Hill:1996:p.161-76.

23. Worek F, Widmann R, Knopff O, Szinicz L. Reactivating potency of obidoxime, pralidoxime, HI-6 and Hlö-7 in human erythrocyte acetylcholinesterase inhibited by highly toxic organophosphorus compounds. Arch Toxicol 1998;72:237-43.

Submitted April 2004

Accepted April 2004.

Doc. MUDr. Jiří Kassa, CSc.,

Purkyně Military Medical Academy, P.O. Box 35/T, 50001 Hradec Králové,

Czech Republic. e-mail: kassa@pmfhk.cz 